Journal of Epidemiology and Public Health (2016), 1(1): 66-74

https://doi.org/jepublichealth.2016.01.01.08

\title{
Association between the Socioeconomic Factors, Healthy Home, and Healthy Behavior among Parents of Children Underfive with Acute Respiratory Infection in Kediri, Indonesia
}

\author{
Tiyan Anggraini'), Ambar Mudigdo²), RB.Soemanto3) \\ ${ }^{1)}$ School of Health Sciences, Kadiri University, Kediri \\ 2)Faculty of Medicine, Sebelas Maret University \\ 3)Faculty of Social and Political Sciences, Sebelas Maret University
}

\begin{abstract}
Background: Acute Respiratory Infection or ARI is the primary cause of death in children underfive. Many factors may cause to its high incidence among others are socio-economic, healthy home and healthy behavior of parents. This study aimed to determine the association between socio-economic and healthy home among parents of children underfive with Acute Respiratory Infection.

Subjects and Method: This was a case control study conducted in Kediri, East Java, Indonesia. A total sample of 100 children underfive was selected for this study, consisting of 20 children with and 80 children without ARI. The dependent variable was ARI preventive behavior among parents of children with ARI. The independent variables included education, family income, housing components, sanitation. The data were collected by pre-tested questionnaire, and analyzed using a multiple logistic regression model.

Results: High education $(\mathrm{OR}=9.1 ; 95 \% \mathrm{CI}=0.8$ to $98.4 ; \mathrm{p}=0.001)$, high family income $(\mathrm{OR}=$ $1.3 ; 95 \% \mathrm{CI}=0.1$ to $14.2 ; \mathrm{p}<0.001)$, good housing components $(\mathrm{OR}=4.0 ; 95 \% \mathrm{CI}=0.5$ to $27.7 ; \mathrm{p}=$ 0.005), good sanitation ( $\mathrm{OR}=6.9 ; 95 \% \mathrm{CI}=1.1$ to $41.9 ; \mathrm{p}=0.001)$, and other family member healthy behavior $(\mathrm{OR}=8.9 ; 95 \% \mathrm{CI}=1.6$ to $48.7 ; \mathrm{p}=0.003)$ increased the likelihood of parental ARI preventive behavior.

Conclusion: education, family income, housing components, sanitation, and other family member healthy behavior have positif association with parental ARI preventive behavior.
\end{abstract}

Keywords: education, family income, housing components, sanitation, parental ARI preventive behavior.

\section{Correspondence:}

Tiyan Anggraini. School of Health Sciences, Kadiri University, Kediri, Indonesia.

Email:tiyananggraini@yahoo.co.id

\begin{tabular}{l}
\hline BACKGROUND \\
\hline Acute Respiratory Infection (ARI) is kind of \\
respiratory infection ranging from nasal \\
cavity up to epiglottis and larynx by \\
showing some symptoms like fever, cough, \\
influenza, otitis media and also acute \\
faringitis. Acute Respiratory Infection is \\
one of the respiratory diseases which is it \\
more painful when the air is so humid, cold \\
or the weather is too hot.This kind of \\
disease might cause complication of disease
\end{tabular}

\section{BACKGROUND}

Acute Respiratory Infection (ARI) is kind of respiratory infection ranging from nasal cavity up to epiglottis and larynx by showing some symptoms like fever, cough, inluenza, otitis media and also acute faringitis. Acute Respiratory Infection is one of the respiratory diseases which is it more painful when the air is so humid, cold disease might cause complication of disease and it was not cured right away (Mochtar, 2008).

One of diseases which is often suffered by the society is ARI including upper and lower ARI. Acute Respiratory Infection were suffered mostly by the children in both developing and developed country (WHO, 2003). This disease is also one of causes of death which is mostly happened in both country. It was estimated that ARI caused approximately 4 of 15 million death among children underfive 
each year. Two-third of those deaths were infants (WHO, 2003).

Acute Respiratory Infection rate places high number level in Indonesia, its case could reach up to 260.000 cases. At the end of 2011, there were 6 cases of ARI including 1000 of infants and children underfives. In 2013, there were 5 of 1000 infants whom they suffered the diseas because of unhealthy house (Supraptini, 2014). There were 5 cases among the 1000 infants and children underfives. Acute Respiratory Infection affected 150,000 infants or children underfives died or 12,500 victims of each month or 416 case of each day or 17 children of each hour or every 5 minutes an infants died (Siswono, 2007).

Based on National EconomiSocail Survey (SUSENAS) 2014, unhealthy house were classified into 3 categories, they were good, middle, and bad. Good category of healthy house reached $35.3 \%$, middle level was $39.8 \%$ and bad category was $24.9 \%$. Indonesia targeted to reach good category for healthy house is around 80\%, however it cannot reach the target. Therefore, healthy houses cannot reach the target (Depkes RI, 2014). According to Indonesian Demography Survey Result (SKDI) 20122013, it was said that the death rate of infants was around 35/100o of births. 4 of 15 million was estimated around 4 of 15 million of the children who were under 5 years in each year and two-thirds of the deaths were infants. In 2015, it was recorded tha around $22.30 \%$ of infants or children underfives died because of ARI.

According to Riskesdas data in 2017, ARI was the top two cause of infants' death. All the death rate which are caused by ARI covered 20\%-30\% and the biggest death cause rate is because of pneumonia. It is because the 2-year-old infants were not having right treatment (Ministry of health
RI, 2011). Acute Respiratory Infection prevalensi rate in Indonesia reached up to $0.76 \%$ with the interval between the province aroun $0-13.2 \%$.

The highest prevalensi is Gorontalo with (132\%) and Bali (12.9\%), while other provinces reached $10 \%$. In 2013, the rate of the infants who suffered ARI was around 22.5\%. The percentage of patients increased from 2012 which was $14.98 \%$, however it was still far from Minimum Service Standard (SPM) that was 100\% which might be possibly caused by the estimating rate of patients used the uncertainity of estimating rate of infants (Health Department of East Java, 2014). Based on the report of 2013, there were 898 cases which they were dominated by a year-old up to 4 year-old infants by obtaining IR 1.99\%. In 2014, there were 2529 cases of ARI at Tiron clinic. Most of the patients were 1 up to 59 months which they obtained the incidence Rate (IR) around 1.09\% (Tiron clinic, 2014).

Ventilation can affect occupants' health. Good air circulation can get rid of bacteria. Poor ventilation may also cause humid room, because of the evaporation of the liquid from the skin. Therefore, high level of humidity house becomes a good media for the bacteria to breed which is as cause of ARI.

House sanitation and environment had tight relation toward the contaminate disease rate, especially ARI (Taylor, 2012). Some factors might stimulate the ARI itself like house condition, house cleanliness, occupant solidity and air pollution in house (Iswarini and Wahyu, 2006). Other factors like occupants, ventilation, temperature, and lighting might possibly stimulate the disease (Ambarwati and Dina, 2007).

According to Ranuh (2007), the inappropriate window might cause bad air circulation so it makes the infants and 
Journal of Epidemiology and Public Health (2016), 1(1): 66-74

https://doi.org/jepublichealth.2016.01.01.08

children often inhale the cigarette smoke and kitchen smoke. Therefore, they are easier attacked the ARI. Humid and wet house and also slightly sunrise caused the occupants attacked ARI easier because the wall cannot absorb the water well so it makes the wall wet. Based on the result of study conducted by Yusup and Sulistyorini (2005), it was said that there was a correlation between ventilasi, lighting and occupants' behavior and ARI. Therefore, the risk will be twice bigger toward the children underfives with low immune system (Muluki, 2004).

Many factors affected high ARI incidence such as housing, socio-economy, and healthy behavior of parents in raising the children to get care needs and caring in order to keep their health, so that the children are expected to have healthy physics, mentality, social and spiritual. Acute Respiratory Infection disease for infants can be prevented through healthy house, healthy occupants' behavior and children underfives' nutrition improvement as well as parenting in healthy improvement for children underfive (Depkes, 2005).

This study aimed to determine the association between socio-economic and healthy home among parents of children underfive with Acute Respiratory Infection.

\section{SUBJECTS AND METHOD}

This was a case control study. The study aimed to investigate the relationship between the parental healthy behavior of children underfive with ARI toward education, family income, house components, sanitation and other family member beha- vior. This was conducted in UPTD Tiron clinic in Kediri, East Java and it was started during June to July in 2016.

The population was 100 subjects of infants and infants' parents. Fixed diseases sampling technique was conducted in this study. Independent variables of this study were education, house components, sanitation and other family member behavior, meanwhile dependent variables was paents' behavior of infants with ARI. The instrument used questionnaire and data analysis by using multiple logistic regression.

\section{RESULT}

The study was conducted in Tironclininc in Kediri regency. There were 100 subjects of the study consisting of 20 subjects for case and 80 subjects for control.

According to the result of logistic regression multivariate analysis on the Table 3, it was explained that the relationship between independent and dependent variable. Education variable explained that the score showed statistically significant ( $\mathrm{p}=0.001)$ which meant it had strong relationship between education and parents' behavior of infants with Acute Respiratory Infection (ARI). Lower education might have bad behavior 9.1 higher that those who had high education $(\mathrm{OR}=9.1 ; 95 \%$ $\mathrm{CI}=0.8$ to $98.4 ; \mathrm{p}=0.001)$. Income variable can be explained through the score $(\mathrm{p}=$ o.001) and it was statistically significant meaning that there was strong positive influence between income and parents' behavior of infants with ARI. Lower family income might have worse behavior 1.3 higher than those who had high income $(\mathrm{OR}=1.3 ; 95 \% \mathrm{CI}=0.1$ to $14.2 ; \mathrm{p}=0.001)$.

Table 1. The subject study's characteristics

\begin{tabular}{llccccc}
\hline \multirow{2}{*}{ Characteristics } & \multirow{2}{*}{ Category } & \multicolumn{2}{c}{ Case } & \multicolumn{2}{c}{ Control } \\
\cline { 2 - 6 } & & $\mathbf{N}$ & $\mathbf{( \% )}$ & $\mathbf{N}$ & (\%) \\
\hline Education & High & 5 & 25 & 43 & 53.8
\end{tabular}


Anggraini et al./ Association between the Socioeconomic Factors, Healthy Home

\begin{tabular}{llcccc} 
& Low & 15 & 75 & 37 & 46.2 \\
Income & High & 5 & 25 & 42 & 52.5 \\
Housing & Low & 15 & 75 & 38 & 47.5 \\
Components & Healthy & 6 & 30 & 76 & 95 \\
\multirow{2}{*}{ Sanitation } & Unhealthy & 14 & 70 & 4 & 5 \\
\multirow{2}{*}{ Occupants' behavior } & Healthy & 6 & 30 & 15 & 18.8 \\
& Unhealthy & 14 & 70 & 65 & 81.2 \\
& Healthy & 7 & 35 & 19 & 23.8 \\
& Unhealthy & 13 & 65 & 61 & 76.2 \\
\hline
\end{tabular}

Table 2. Bivariate Analytical Result

\begin{tabular}{|c|c|c|c|c|c|c|}
\hline \multirow[t]{2}{*}{ Variable } & \multicolumn{4}{|c|}{$\begin{array}{c}\text { Children underfive parents' healthy } \\
\text { behavior }\end{array}$} & \multirow[t]{2}{*}{ OR } & \multirow[t]{2}{*}{$\mathbf{P}$} \\
\hline & Unhealthy & $\%$ & Healthy & $\%$ & & \\
\hline Education & & & & & 21.8 & 0.001 \\
\hline Low & 41 & 41 & 11 & 11 & & \\
\hline High & 7 & 7 & 41 & 41 & & \\
\hline Income & & & & & 11.7 & 0.001 \\
\hline Low & 39 & 39 & 14 & 14 & & \\
\hline High & 9 & 9 & 38 & 38 & & \\
\hline Housing components & & & & & 4.9 & 0.005 \\
\hline Unhealthy & 14 & 14 & 4 & 4 & & \\
\hline Healthy & 34 & 34 & 48 & 48 & & \\
\hline Sanitation & & & & & 13.2 & 0.001 \\
\hline Unhealthy & 46 & 46 & 33 & 33 & & \\
\hline Healthy & 2 & 42 & 19 & 19 & & \\
\hline \multicolumn{7}{|l|}{ Occupants' Behavior } \\
\hline Unhealthy & 42 & 42 & 32 & 32 & 4.3 & 0.003 \\
\hline Healthy & 6 & 6 & 20 & 20 & & \\
\hline
\end{tabular}

Table 3. Multiple logistic regression analysis result

\begin{tabular}{|c|c|c|c|c|}
\hline \multirow{2}{*}{ Variable } & \multirow{2}{*}{ OR } & \multicolumn{2}{|c|}{$95 \% \mathrm{CI}$} & \multirow[b]{2}{*}{$\mathbf{p}$} \\
\hline & & Upper Limit & Lower Limit & \\
\hline Education & 9.1 & 0.08 & 98.4 & 0.001 \\
\hline Income & 1.3 & 0.1 & 14.2 & 0.001 \\
\hline Housing components & 4.0 & 0.5 & 27.7 & 0.005 \\
\hline Sanitation & 6.9 & 1.1 & 41.9 & 0.001 \\
\hline Other family member behavior & 8.9 & 1.6 & 48.7 & 0.003 \\
\hline $\mathrm{N}$ observation & 100 & & & \\
\hline -2 Log Likelihood & 80.0 & & & \\
\hline Nagelkerke R square & $59 \%$ & & & \\
\hline
\end{tabular}

The score obtained from house components variable was $(\mathrm{p}=0.005)$ meaning that there was strong positive influence between house components and parents' behavior of infants with ARI, and the result stated that it was statistically significant. The unhealthier the house component is the worse the behavior is which was showed on point of 4.0 higher than those with healthy house components $(\mathrm{OR}=4.0 ; 95 \%$ $\mathrm{CI}=0.5$ to $27.7 ; \mathrm{p}=0.005)$. Sanitation variable obtained score $(\mathrm{p}=0.001)$ which meant that it was statistically significant by obtaining strong positive influence between 
Journal of Epidemiology and Public Health (2016), 1(1): 66-74

https://doi.org/jepublichealth.2016.01.01.08

sanitation and parents' behavior of infants with ARI. The more unhealthy the sanitation is the higher the the risk of bad behavior will be. It reached point 6.9 higher than those who got healthy sanitation (OR $=6.9 ; 95 \% \mathrm{CI}=1.1$ to $41.9 ; \mathrm{p}=0.001)$.

Occupants' behavior obtained ( $\mathrm{p}=$ o.003) which meant there was a strong positive correlation between occupants' parents' behavior of children underfives with Acute Respiratory Infection (ARI) and it was proved statistically significant. The unhealthier the occupants' behavior is, it will risk 8.9 higher than healthy occupants' behavior $(\mathrm{OR}=8.9 ; 95 \% \mathrm{CI}=1.6$ to 48.7 ; $\mathrm{p}=0.003$ ).

\section{DISCUSSION}

The result showed that there was a correlation between the education level and healthy parents' behavior of infants with ARI, it can be seen through the result of the data percentage which was unhealthy parents' behavior and low education level placed (41\%) and high education level got (7\%). Meanwhile the healthy parents' behavior with low educationlevel performed (11\%) and high education level got (41\%). According to the data percentage, it can be said that there was a correlation which was high education level had unhealthy behavior lower than low education level. The statistic result showed that there was a positive correlation between education level and parents' health behavior of infants with ARI and it was statistically significant.

The result was similar with the study conducted by Amalia (2009) whose the study showed that education affected someone's health behavior. In her study, it was obtained that those whom the education level was senior high school level and having healthy behavior performed 20\% bigger than those whose the education was elementary or no having education $5 \%$. The result was similar to the study carried out by Goodman (2001) which was high education level maintained their healthy more than low education level. High education level tends to direct the subject to have preventive action, know more about healthy problem and have healthy level of life better (Widyastuti, 2005). The education enhaces intellectual level. The intellectual itself affects to knowledge, way of thinking whether making a decision or making a policy. The higher the formal education is, the better the knowledge of health is (Hastono, 1997).

Unhealthy and low income subjects obtained (39\%) and high income was (9\%). Meanwhile healthy and low income subjects performed (14\%) and high income was (38\%). Based the result above, it tended to have a correlation. High income precentage had unhealthy behavior lower than low income percentage. Statistically, the result showed significant. There was a positive correlation between income level and healthy parents' behavior of children underfives with ARI.

The result was in line with the study conducted by Amalia (2009). Income affected someone's healthy behavior. The result above showed that low income level behave unhealthy life bigger (50\%). The result of this study was hand in hand with the study conducted by Mollo (1995). It was said that income level correlated ti poverty which might affect to society healthy level. The other factors are kinds of job, family's head formal education, family member and so on (Sumiarto, 1993). The result also was similar to the study carried out by Widoyono (2008). It was stated that income factor was one of the factors which affected society's knowledge about environment sanitation.

From housecomponent factor, it was obtained that unhealthy behavior and 
unhealthy component of house (14\%) and healthy component of house (34\%). Meanwhile healthy behavior and unhealthy house component was (4\%) and healthy house component was (48\%). Based the percentage, it can be concluded that unhealthy house component had unhealthy behavior worse than healthy component house. Statistically result, it showed that a positive correlation between house components and healthy parents' behavior of children underfives with ARI and it was significant.

The result was similar to the study conducted by Triska (2005). House components affected someone to have healthy behavior. The study was carried out in 3 different location and the result obtained was the same for the occupant solidity and Acute Respiratory Infection case for infants (ARI). Occupant solidity obtained the significant result for the infants who suffered from ARI by showing the score $\mathrm{p}<0.05$. Most of the subject did not meet the occupant solidity requirement. This was caused by the capacity of the house. So they cannot make a proper healthy room. Occupant solidity was related to acute respiratory infection's transmition (Krieger and Higgins, 2002).

From the sanitation factor, it was obtained that the percentage of unhealthy behavior and unhealthy sanitation was 46 (46\%) and healthy sanitation had 2 (2\%). Meanwhile the percentage of healthy behavior and healthy sanitation was 19 (19\%) and unhealthy sanitation was 33 (33\%). According to the result, it was shown that the percentage of unhealthy sanitation had unhealthier behavior than those who considered healthy sanitation. The result was statistically significant by showing the positive correlation between sanitation and healthy parents' behavior for infants with ARI.
The result was in line with the study conducted by Amalia (2009). Sanitation affected someone to have healthy behavior. The study whose it was carried out by Triska showed that the environment sanitation was not maintained well because 27 houses (67.5\%) had dried and dirty floor, 13 house (32.5\%) had wet and dirty floor. The sirculation was not optimal yet because 21 house (52.5\%) did not open window every day which it was supposed to open at least a time a day. The toilet location of 32 houses (80\%) was not located more than 5 meters from disposal site, therefore the dish could be contaminated. This condition became worse by the existence of 9 houses (22.5\%) which they did not have disposal site and 8 houses (20\%) did not have disposal site.

From occupants's behavior factor, the percentage of unhealthy behavior toward the unhealthy occupants' behavior was (42\%) and healthy occupants' behavior was (6\%). While the healthy behavior subjects and unhealthy occupants' behavior obtained (32\%) and healthy occupant subject was 20 (20\%). Form the result obtained, it can be soncluded that there was a correlation which was unhealthy occupants' behavior behaved worse than healthy occupants. From the result, it was shown statistically significant. It was shown that there was a positive correlation between healthy occupants' behavior and healthy parents' behavior of infants with ARI.

The result of this study was similar to the study conducted by YuliTrisnawati (2012). The result obtained the occupants' behavior affected to someone's healthy behavior. In the case group (ARI), the parents' patients whose their smoking habit was categorized in heavy category and the result showe $80.4 \%$. In control group, there were $39(79.5 \%)$ children whom their parents' smoking habit was categorized as light category. It can be concluded through 
Journal of Epidemiology and Public Health (2016), 1(1): 66-74

https://doi.org/jepublichealth.2016.01.01.08

the result above that the worse the parents' smoking habit is, the bigger the risk of the children suffer ARI. The result was supported by the result statistic test by obtaining Chi Square correlation with the score $\mathrm{p}=0.001$ which meant there were a correlation between parents' smoking habit and ARI for infants. By obtaining the score OR 13.32, it meant that the infants with smoker parents had a risk 13.32 times affected by ARI than non-smoker parents. The smoke from smoker parents was serious pollution substance in dwelling room and it will risk more pain from toxic substances to the children.

The result obtained that the education, income, house components, sanitation and occupants' behavior showed the correlation toward the healthy parents' behavior of the infants with ARI and it was obtained the most significan variable toward the healthy parents' behavior which was parents' education.

\begin{tabular}{c}
\hline REFERENCE \\
\hline Handayani D (2008). Hubungan Antara \\
Rumah Tangga Sehat Dengan Kejadi- \\
an Pnemonia Pada Balita. Universitas \\
Sebelas Maret.
\end{tabular}

Indriyani WN (2008). Panduan Praktis Mendidik Anak Cerdas Intlektual Dan Emosional. Yogyakarta: Logung Pustaka.

Isnawati (2006). Pengaruh Kondisi Lingkungan Fisik Rumah dan Perilaku Penduduk terhadap Kejadian Penyakit ARI pada Anak Balita: Studi di Desa Tual Kecamatan Kecil Kabupaten Maluku Tenggara. Skripsi. Surabaya: Fakultas kesehatan Masyarakat Universitas Airlangga.

Marimbi H (2010). Tumbuh Kembang Status Gizi Dan Imunisasi Dasar Pada Balita. Yogyakarta: Nuha Medika.
Mochtar (2008). Infeksi Saluran Pernapasan Akut (ARI) dan penanggulangannya. Diakses dari:http://viethanurse.wordpress/asuhan-keperawatananak-preschool-dengan-ARI. Diakses tanggal 5 Februari 2016.

Mukono HJ (2009). Prinsip Dasar Kesehatan Lingkungan. Surabaya: Airlangga University Press.

Muluki M (2004). Analisis factor risiko yang berhubungan dengan terjadinya penyakit ARI di Puskesmas Palanro Kecamatan Mallusetasi Kabupaten Baru Tahun 2003. Badan Penelitian dan Pengembangan Kesehatan Departemen Kesehatan.

Murti B (1997). Prinsip Dan Metode Riset Epidemiologi, UGM: Yogyakarta.

Oktaviana VA (2009). Hubungan Antara Sanitasi Fisik Rumah dengan Kejadian Infeksi Saluran Pernapasan Atas (ARI) pada Balita Di Desa Cepogo Kecamatan Cepogo Kabupaten Boyolali. (Online).http://etd.eprints.ums.ac.id/5965/1/J410050018.PDF. Diakses 30 November 2012.

Ranuh IGN (2007). Masalah ARI dan Kelangsungan Hidup Anak. Surabaya, Continuing Education. Ilmu Kesehatan Anak.

Siswanto (2010). Infeksi Saluran Pernapasan Akut. Terdapat pada http://prabu.wordpress.com/2009/01/04/infeksisaluran-pernafasan-akutARI. Diakses 15 Februari 2016.

Suparitni (2008). Gambaran Rumah Sehat di Indonesia. http://lib.atmajaya.ac.id/default.aspx?tabID=52\&prang= Supartini. Diakses 15 Februari 2016.

Taylor V (2012). Health Hardware for Housing for Rural and Remote Indigenous Communities.Australia: Central Australian Division of General Practice. 
Anggraini et al./ Association between the Socioeconomic Factors, Healthy Home

Trisnawati (2012). Hubungan Perilaku Merokok orang tua dengan kejadian ARI pada balita di wilayah kerja puskesmas tembang Kabupaten Purbalingga: Purwokerto.
Winarni (2010). Hubungan antara Perilaku Merokok Orang Tua dan Anggota Keluarga yang Tinggal dalam Satu Rumah dengan Kejadian ARI pada Balita Jurnal Ilmiah Kesehatan Keperawatan, 6(1). 